\title{
Evaluation of the Effect of GnRH Analogue, Progesterone and Tolfenamic Acid on Serum Progesterone Profile and Conception Rate in Repeat Breeding Crossbred Cattle
}

\author{
Sudhanshu Pratap Singh ${ }^{*}$, Ankesh Kumar ${ }^{2}$, Prakrutik Prafulchandra Bhavsar ${ }^{3}$, \\ Mukesh Sahu ${ }^{4}$, Praveen Kumar ${ }^{1}$ and Sushil Kumar ${ }^{5}$
}

${ }^{1}$ Department of Veterinary Gynaecology and Obstetrics, ${ }^{2}$ Department of Veterinary Clinical

Complex, ${ }^{5}$ Department of Veterinary Medicine, Bihar Animal Sciences University, Patna, Bihar, India

${ }^{3}$ College of Veterinary Science and Animal Husbandry, Anand Agricultural University, Anand, Gujarat, India

${ }^{4}$ Department of Veterinary Gynaecology and Obstetrics, College of Veterinary Animal

Sciences, G. B. Pant University of Agriculture and Technology, Pant Nagar, Uttarakhand, India

*Corresponding author

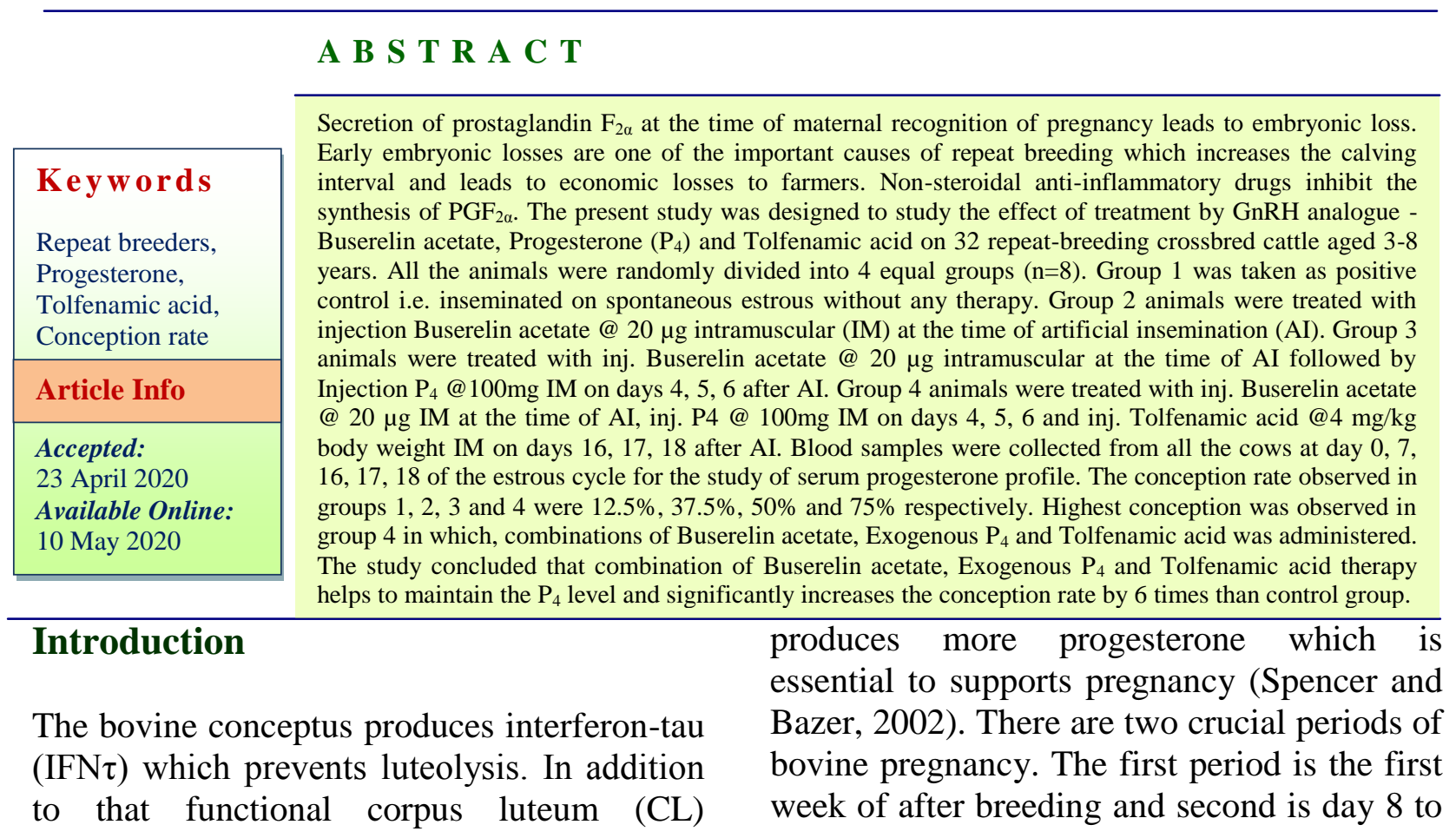


28, when maternal recognition of pregnancy (MRP) takes place. Approximately 32\% of total embryonic loss occurs in this period (Wiltbank et al., 2016). This leads to a repeat of oestrous. Repeat breeding (RB) is a considerable problem in cattle breeding which leads to large economic losses due to more inseminations, increased calving interval and increased culling rates. Repeat breeding has been defined as the failure to conceive from 3 or more regularly spaced services in the absence of detectable abnormalities (Bartlett et al., 1986).

Several factors like nutritional stress (Bender et al., 2014), heat stress (Sakatani, 2017), transportation stress (Merrill et al., 2007) or other stress promotes secretion of prostaglandin $F_{2 \alpha}$ from the uterine endometrium. This can cause lysis of the functional corpus luteum and leads to early embryonic death (Hockett et al., 2004). The two cyclooxygenase (COX) enzymes convert arachidonic acid into prostaglandin- $\mathrm{H} 2$ which is further converted into $\mathrm{PGF}_{2 \alpha}$ through the enzyme prostaglandin-F-synthase. The NSAIDs exhibits anti-inflammatory activity mainly based on the inhibition of the cyclooxygenase (COX) enzyme, results in inhibition of prostaglandin synthesis (Malm and Borisch, 2015).

Several studies evaluated the effects of NSAIDs like Flunixine meglumine (Kasimanickam et al., 2019, 2018) and meloxicam (Amiridis et al., 2009; McDougall et al., 2016). Administration of the NSAID tolfenamic acid has significantly improved embryo transfer rate and pup delivery in mice (Schlapp et al., 2015).

Administration of $\mathrm{GnRH}$ or $\mathrm{GnRH}$ analogue before artificial insemination induce preovulatory LH (luteinizing hormone) surge which controls ovulation, or post inseminations with supplementation of exogenous $\mathrm{P}_{4}$ to support early embryonic development (Amiridis et al., 2009). At days 3 to 5 post-ovulation, the embryos usually enter the uterus, undergoing genomic activation and increases in $\mathrm{P}_{4}$ concentration; therefore, this may be a physiologically important time in the cattle, so the administration of a low dose of $\mathrm{P}_{4}$ on days 4, 5 and 6 of the oestrous cycle increase the conception rate among repeat breeder cattle (Ferguson et al., 2012).

This extends the life span of the bovine corpus luteum (CL) so this is one of the strategies aimed at reducing embryo loss by inhibiting the $\mathrm{PGF}_{2 \alpha}$ in the endometrium during the critical period (Binelli et al., 2001; Pugliesi et al., 2011), Inhibition of PGF2 $\alpha$ enhances the CL lifespan and avoiding detrimental and toxic effects of PGF $2 \alpha$ on the embryo (Binelli et al., 2001).

\section{Materials and Methods}

\section{Preparation of animals before commencement of treatment}

The study was conducted on 32 apparently healthy, 3-8 years old repeat breeding crossbred cattle. All animals were dewormed with Fenbendazole @ 7.5 mg per kg body weight 60 days prior to the commencement of experiment and they were supplemented with $40 \mathrm{gm}$ mineral mixture daily prior to experiment.

\section{Grouping of animals and treatment}

Selected animals were randomly divided into four groups (each group containing 8 animals). In group 1, animals were inseminated on spontaneous estrous without any treatment, in group 2, animals were treated with injection Buserelin acetate @ 20 $\mu \mathrm{g} I \mathrm{M}$ at the time of artificial insemination (AI), in group 3, animal were treated with 
injection Buserelin acetate @ $20 \mu \mathrm{g}$ IM at the time of AI followed by Injection $\mathrm{P}_{4} @ 100 \mathrm{mg}$ IM on days 4,5,6 after AI and in group 4, animals were treated with injection Buserelin acetate @20 $\mu \mathrm{g}$ IM at the time of AI, Injection $\mathrm{P}_{4} @ 100 \mathrm{mg} \mathrm{IM}$ on days 4,5,6 and Inj. Tolfenamic acid @ 4 mg/kg body weight IM On days 16,17,18 after AI. All the animals were inseminated on spontaneous heat (Table 1).

\section{Blood collection and hormonal assay}

Assuming estrous day as day 0, blood samples was collected in clot activator from all the cows at day $0,7,16,17,18$ of the cycle to harvest for hormonal estimation (Table 1). Level of $\mathrm{P}_{4}$ in blood was estimated by RadioImmuno Assay (RIA) Progesterone essay kit (M/S Beckman Coulter, Brea, CA) catalogue no. IM 1188 as per the suggested protocol. In brief all reagents were brought to the room temperature $\left(20-25^{\circ} \mathrm{C}\right)$ before assaying.

For estimation of serum progesterone, $50 \mu 1$ standard and $50 \mu 1$ serum sample were taken into antibody coated tubes. $500 \mu 1{ }^{125} \mathrm{I}$ labelled serum progesterone was added to each antibody-coated tube.

Two additional non-coated tubes were prepared for total activity computation containing $500 \mu \mathrm{l}$ tracer $\left({ }^{125}\right.$ I-labelled serum progesterone) and was set-aside until counting. The contents of the tubes were mixed with a vortex and incubated for $1 \mathrm{hr}$ for serum progesterone estimation at room temperature, while continuously shaking (300-350 rpm).

The incubation mixture was carefully aspirated while aspirator tip touched the bottom of the antibody coated tube so that all the liquid was removed. The radioactivity was measured with SR-300 fully automatic gamma counter.
Statistical analysis of the effect of different treatments between the groups and within the group on different days and serum $\mathrm{P}_{4}$ concentration in of repeat breeder cows was studied by repeated measures ANOVA. The multiple comparisons between group, day and interaction for different parameters were done by using Tukey test at 5\% level of significance. The analysis was done using JMP 9.0 software.

\section{Results and Discussion}

\section{Conception rate}

The conception rates observed in the present work in all four groups were $12.5 \%, 37.5 \%$, $50 \%$ and $75 \%$ respectively in group 1, group 2 , group 3 and group 4 . The highest conception rate was observed in group 4.

In a similar study by Amiridis et al., (2009) reported highest conception rate of $33.76 \%$ in repeat breeder cows which is lower conception rate than the present study. (Aguiar et al., 2013) they reported conception rate of $66.70 \%$ with the use of meloxicam- a NASID and this is comparable with the present finding while they obtained $49 \%$ Conception rate in the control group which is higher than the present report. Archbald et al., (1993) used GnRH at the time artificial insemination and reported the conception rate ranging from $33 \%-40 \%$ this is comparable to the present finding (Fig. 2).

While using progesterone in a low dosage by (Ferguson et al., 2012) in an experiment observed conception rate of $45 \%$ which slight lower than the present finding.

Highest conception rate in present study was observed in group 4 i.e. $75 \%$, where treatment had been given with combinations of $\mathrm{GnRH}$ analogue (Busereline acetate), Exogenous progesterone and non-steroidal anti- 
inflammatory drug (Tolfenamic acid). All the treatments were given at different days of estrus cycle when the chances of conception failure are more i.e. Buserelin acetate on day 0 when time of ovulation depend on concentration of LH which is govern by release of GnRH, then Progesterone injected on day 4, 5 and 6 when embryo travels from horn to uterus and Tolfenamic acid was given on day 16, 17 and 18 when MRP process are going on.

Least conception rate observed in group 1 in which no treatment was given and kept as a control. The combined administration of GnRH, Progesterone, and NSAID was effective in treatment of the repeat breeder cows.

\section{Serum progesterone profile}

\section{In group 1}

The mean total P4 concentration on day 0,7 , 16,17 and 18 was $0.31 \pm 0.06,2.31 \pm 0.27$, $3.99 \pm 0.23,4.63 \pm 0.29$ and $4.40 \pm 0.31 \mathrm{ng} / \mathrm{ml}$, respectively. The significant $(\mathrm{p}<0.05)$ differences were observed between days, significantly higher level were observed on days 16,17 and 18 compared to days 0 and 7 .

\section{In group 2}

The mean total P4 concentration on day 0,7 , 16,17 and 18 was $0.37 \pm 0.06,2.47 \pm 0.27$, $5.06 \pm 0.47,6.37 \pm 0.40$ and $7.08 \pm 0.52 \mathrm{ng} / \mathrm{ml}$, respectively. The significant differences were observed between days, significantly $(p<0.05)$ higher level were observed on days 17 and 18 compared to days 16, 7 and 0 . The nonsignificant difference was observed among days 16, 17 and 18 (Fig. 1).

\section{In group 3}

The mean total P4 concentration on day 0,7 , 16,17 and 18 was $0.42 \pm 0.05,2.81 \pm 0.23$,
$4.67 \pm 0.46,5.69 \pm 0.49$ and $6.44 \pm 0.58 \mathrm{ng} / \mathrm{ml}$, respectively. The significant differences were observed between days, significantly $(\mathrm{p}<0.05)$ higher level were observed similarly as in previous group on days 17 and 18 compared to days 16,7 and 0 .

\section{In group 4}

The mean total P4 concentration on day 0,7 , 16,17 and 18 was $0.44 \pm 0.06,2.71 \pm 0.22$, $5.14 \pm 0.48,7.13 \pm 0.46$ and $8.41 \pm 0.54 \mathrm{ng} / \mathrm{ml}$, respectively. The significant differences were observed between days, significantly higher level were observed similarly as in previous group on days 17 and 18 compared to days 16, 7 and 0 (Table 2).

The significantly $(\mathrm{p}<0.05)$ highest level of progesterone was observed on day 18 in group 4 and group 2 among all the treatment groups and levels were $8.41 \pm 0.54$ and $7.08 \pm 0.52 \mathrm{ng} / \mathrm{ml}$ respectively. The rising trend of serum progesterone was observed in all the treatment groups on days $0,7,16,17$ and 18 and significant differences $(\mathrm{p}<0.05)$ was observed on days 17 and 18 between groups.

On the day 17 and 18 of group 4, on the administration of tolfenamic acid the mean serum progesterone concentration was $7.13 \pm 0.46$ and $8.41 \pm 0.54 \mathrm{ng} / \mathrm{ml}$ respectively which was significantly higher between the treatments which might have luteotropic effect on corpus luteum, leading to increase in serum progesterone concentration.

The similar observations were reported by (Jaroszewski et al., 2009; Maithani, 2017; von Krueger and Heuwieser, 2010). The reason of this highest serum progesterone levels in group 4 of the present experiment was the combine administrations of GnRH analogue, Progesterone and Tolfenamic acid. 
Table.1 Dose and dosage schedule of drugs in different treatment group

\begin{tabular}{|c|c|c|c|}
\hline $\begin{array}{l}\text { Cattle groups } \\
(\mathrm{N}=8 \text { in each group })\end{array}$ & Treatment & Day of treatment & $\begin{array}{l}\text { Day and time of } \\
\text { blood collection }\end{array}$ \\
\hline Group-1 (Control) & No treatment & No treatment & $\begin{array}{l}\text { At days } 0,7,16,17 \text {, } \\
18 \text { of estrous cycle }\end{array}$ \\
\hline Group- 2 & $\begin{array}{l}\text { Inj.Buserelin Acetate@20 } \\
\mu \mathrm{g} \text { IM }\end{array}$ & At the time of AI & $\begin{array}{l}\text { At days } 0,7,16,17, \\
18 \text { of estrous cycle }\end{array}$ \\
\hline \multirow[t]{2}{*}{ Group -3 } & $\begin{array}{l}\text { Inj.Buserelin Acetate @ } \\
20 \mu \mathrm{g} \text { IM }\end{array}$ & At the time of AI & \multirow{2}{*}{$\begin{array}{l}\text { At days } 0,7,16,17 \text {, } \\
18 \text { of estrous cycle }\end{array}$} \\
\hline & $\begin{array}{l}\text { Inj.Progesterone@100mg } \\
\text { IM }\end{array}$ & $\begin{array}{l}\text { On days } 4,5,6 \text { after } \\
\text { AI }\end{array}$ & \\
\hline \multirow{3}{*}{ Group -4 } & $\begin{array}{l}\text { Inj.Buserelin acetate @ } 20 \\
\mu \mathrm{g} \text { IM }\end{array}$ & At the time of AI & \multirow{3}{*}{$\begin{array}{l}\text { At days } 0,7,16,17 \text {, } \\
18 \text { of estrous cycle }\end{array}$} \\
\hline & $\begin{array}{l}\text { Inj.Progesterone@100mg } \\
\text { IM }\end{array}$ & $\begin{array}{l}\text { On days } 4,5,6 \text { after } \\
\text { AI }\end{array}$ & \\
\hline & $\begin{array}{l}\text { Inj.Tolfenamic acid @4 } \\
\text { mg/kg b.wt. IM }\end{array}$ & $\begin{array}{l}\text { On days } 16,17,18 \\
\text { after } \mathrm{AI}\end{array}$ & \\
\hline
\end{tabular}

Table.2 Mean $( \pm \mathrm{SE})$ serum $\mathrm{P}_{4}$ concentration $(\mathrm{ng} / \mathrm{dl})$ in different groups on $0,7^{\text {th }}, 16^{\text {th, }} 17^{\text {th }}$ and $18^{\text {th }}$ day of estrous cycle in repeat breeder cows

\begin{tabular}{|l|c|c|c|c|c|}
\hline Group & Day 0 & Day 7 & Day 16 & Day 17 & Day 18 \\
\hline $\mathbf{1}$ & $0.31 \pm 0.06^{\mathrm{I}}$ & $2.31 \pm 0.27^{\mathrm{H}}$ & $3.99 \pm 0.23^{\mathrm{FG}}$ & $4.63 \pm 0.29^{\mathrm{EF}}$ & $4.40 \pm 0.31^{\mathrm{EF}}$ \\
\hline $\mathbf{2}$ & $0.37 \pm 0.06^{\mathrm{I}}$ & $2.47 \pm 0.27^{\mathrm{H}}$ & $5.06 \pm 0.47^{\mathrm{DEF}}$ & $6.37 \pm 0.40^{\mathrm{BCD}}$ & $7.08 \pm 0.52^{\mathrm{AB}}$ \\
\hline $\mathbf{3}$ & $0.42 \pm 0.05^{\mathrm{I}}$ & $2.81 \pm 0.23^{\mathrm{GH}}$ & $4.67 \pm 0.46^{\mathrm{EF}}$ & $5.69 \pm 0.49^{\mathrm{CDE}}$ & $6.44 \pm 0.58^{\mathrm{BC}}$ \\
\hline $\mathbf{4}$ & $0.44 \pm 0.06^{\mathrm{I}}$ & $2.71 \pm 0.22^{\mathrm{GH}}$ & $5.14 \pm 0.48^{\mathrm{CDEF}}$ & $7.13 \pm 0.46^{\mathrm{AB}}$ & $8.41 \pm 0.54^{\mathrm{A}}$ \\
\hline
\end{tabular}

The values bearing the different superscripts across the rows and columns differ significantly from each other, $(\mathrm{P}<0.05)$

Table.3 Conception rate in different group of repeat breeder cows after treatment

\begin{tabular}{|l|c|c|c|c|}
\hline Particulars & GROUP-1 & GROUP-2 & GROUP-3 & GROUP-4 \\
\hline Total no. of animal & 8 & 8 & 8 & 8 \\
\hline Pregnant animal & 1 & 3 & 4 & 6 \\
\hline Conception rate & $12.5 \%$ & $37.5 \%$ & $50 \%$ & $75 \%$ \\
\hline
\end{tabular}




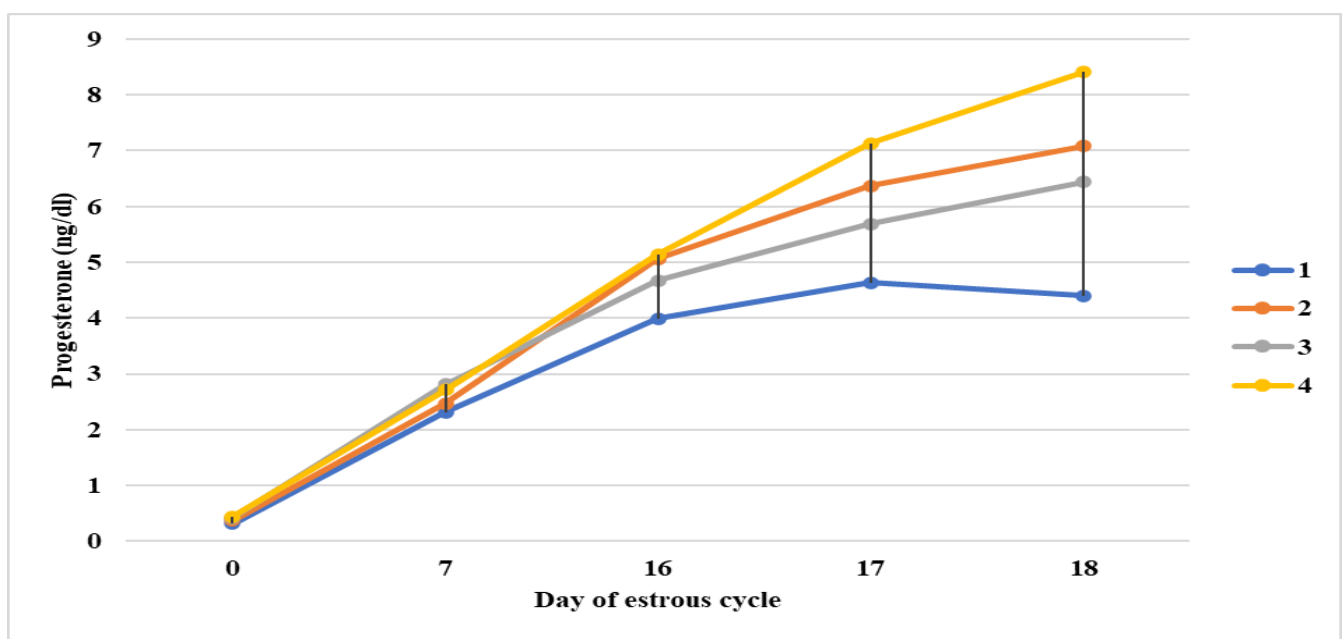

Figure.1 Mean serum $\mathrm{P}_{4}$ concentration (ng/dl) in different groups on $0,7^{\text {th }}, 16^{\text {th, }} 17^{\text {th }}$ and $18^{\text {th }}$ day of estrous cycle in repeat breeder cows

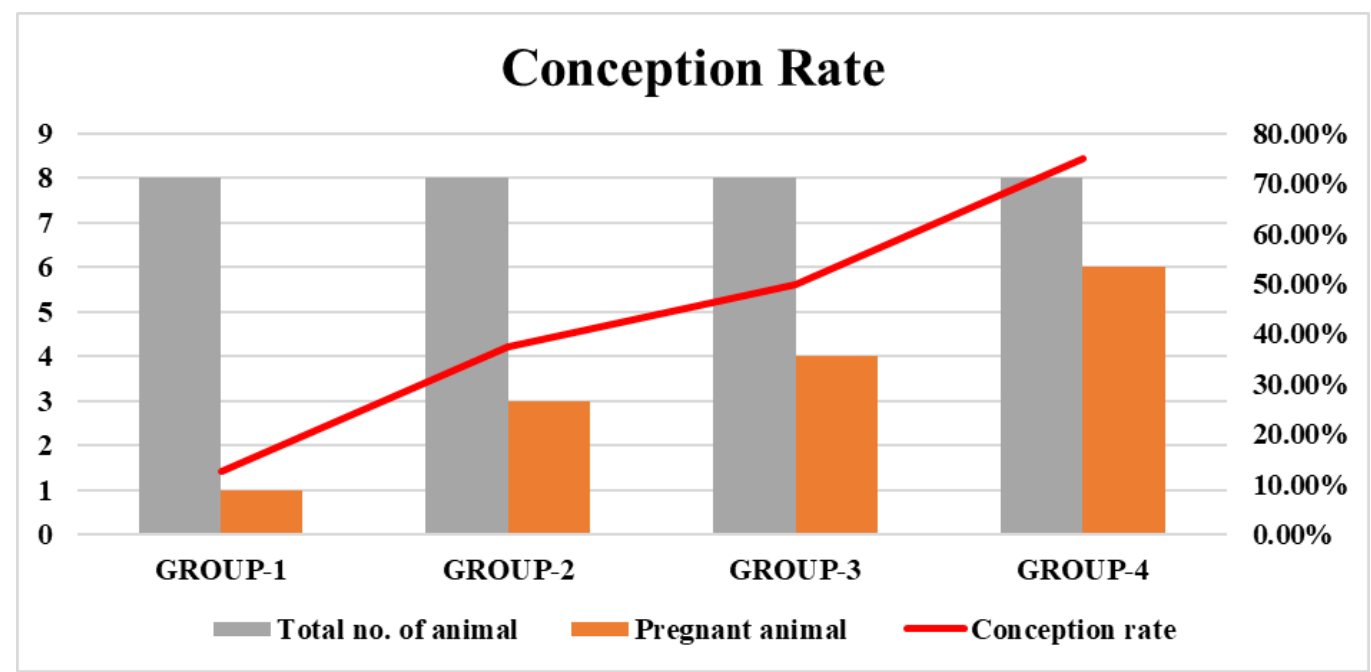

Figure. 2 Conception rate in different group of repeat breeder cows after treatment

The increasing of serum progesterone was observed in all treatment groups simultaneously increasing in conception rate. Since, higher concentration of progesterone in early pregnancy directly related to embryonic growth rate and pregnancy. The significant increase in progesterone was observed in group 4 where combined administrations of Buserelin acetate, Progesterone and Tolfenamic acid were given. Hence, it is concluded that combination therapies of Buserelin acetate, Progesterone and Tolfenamic acid may be beneficial in the treatment of repeat breeding problems.

\section{References}

Aguiar, T.S., Araújo, C. V., Tirloni, R.R., Martins, L.R., 2013. Effect of meloxicam on pregnancy rate of recipient heifers following transfer of in vitro produced embryos. Reprod. in Domes. Anim., 48, 984-988. https://doi.org/10.1111/rda.12197

Amiridis, G.S., Tsiligianni, T., Dovolou, E., Rekkas, C., Vouzaras, D., Menegatos, I., 2009. Combined administration of gonadotropin-releasing hormone, progesterone, and meloxicam is an effective treatment for the repeat- 
breeder cow. Theriogenology, 72(4), 542-548.

https://doi.org/10.1016/j.theriogenology .2009 .04 .010

Barkhori-Mehni, S., Karami-Shabankareh, H., Masoumi, R., Kazemi-Bonchenari, M., Pezeshki, A., Badiei, A., Dirandeh, E. and Colazo, M. G. (2018). Effect of exogenous progesterone or flunixin meglumine after AI on serum progesterone concentration and pregnancy per AI in lactating dairy cows. Anim Reprod., 15(2):140-147. https://doi.org/10.21451/1984-3143AR2017-0014.

Bartlett, P.C., Kirk, J.H., Mather, E.C., 1986. Repeated insemination in Michigan Holstein-Friesian cattle: Incidence, descriptive epidemiology and estimated economic impact. Theriogenology, 26, 309-322. https://doi.org/10.1016/0093691X(86)90150-0

Bender, R.W., Hackbart, K.S., Dresch, A.R., Carvalho, P.D., Vieira, L.M., Crump, P.M., Guenther, J.N., Fricke, P.M., Shaver, R.D., Combs, D.K., Wiltbank, M.C., 2014. Effects of acute feed restriction combined with targeted use of increasing luteinizing hormone content of follicle-stimulating hormone preparations on ovarian superstimulation, fertilization, and embryo quality in lactating dairy cows. J. Dairy Sci., 97(2), 764-778. https://doi.org/10.3168/jds.2013-6926

Binelli, M., Thatcher, W.W., Mattos, R., Baruselli, P.S., 2001. Antiluteolytic strategies to improve fertility in cattle, Theriogenology, 59(9), 1451-1463. https://doi.org/10.1016/S0093-

691X(01)00646-X

Ferguson, C.E., Kesler, D.J., Godke, R.A., 2012. Improving pregnancy rates in problem breeder cattle by administration of $15 \mathrm{mg}$ of progesterone on days 3-5 post-mating. J. App. Anim.
Res., $\quad 40(3), \quad$ 173-178. https://doi.org/10.1080/09712119.2011. 645038

Hockett, M.E., Rohrbach, N.R., Schrick, F.N., 2004. Alterations in embryo development in progestrogensupplemented cows administered prostaglandin F2 $\alpha$. Prostaglandins. Other Lipid Mediat., 73(3-4), 227-236. https://doi.org/10.1016/j.prostaglandins. 2004.02.002

Jaroszewski, J.J., Markiewicz, W., Maślanka, T.S., Skarzyński, D.J., 2009. Influence of nonsteroidal anti-inflammatory drugs on progesterone production by cultured bovine luteal cells. Pol. J. Vet. Sci., 12(3), 305-309.

Kasimanickam, R., Kasimanickam, V., Gold, J., Moore, D., Kastelic, J.P., Pyrdek, D., Ratzburg, K., 2019. Injectable or transdermal flunixin meglumine improves pregnancy rates in embryo transfer recipient beef cows without altering returns to estrus. Theriogenology, 140, 8-17. https://doi.org/10.1016/j.theriogenology .2019 .08 .011

Kasimanickam, R.K., Hall, J.B., Estill, C.T., Kastelic, J.P., Joseph, C., Abdel Aziz, R.L., Nak, D., 2018. Flunixin meglumine improves pregnancy rate in embryo recipient beef cows with an excitable temperament. Theriogenology, 107 , 70-77. https://doi.org/10.1016/j.theriogenology .2017 .10 .043

Koblischke, P., Budik, S., Müller, J. and Aurich, C. (2010). Practical experience with the treatment of recipient mares with a non-steroidal anti-inflammatory drug in an equine embryo transfer programme. Reprod Domest Anim. 45(6):1039-1041. https://doi.org/10.1111/j.14390531.2009.01486.x.

Maithani, M., 2017. Studies on improving 
conception following embryo transfer in cattle. G.B. Pant University of Agriculture and Technology, Pantnagar - 263145 (Uttarakhand).

Malm, H., Borisch, C., 2015. Analgesics, non-steroidal anti-inflammatory drugs (NSAIDs), muscle relaxants, and antigout medications, in: Drugs During Pregnancy and Lactation: Treatment Options and Risk Assessment: Third Edition. pp. 27-58. https://doi.org/10.1016/B978-0-12408078-2.00002-0

McDougall, S., Abbeloos, E., Piepers, S., Rao, A.S., Astiz, S., van Werven, T., Statham, J., Pérez-Villalobos, N., 2016. Addition of meloxicam to the treatment of clinical mastitis improves subsequent reproductive performance. J. Dairy Sci., 99(3), 2026-2042. https://doi.org/10.3168/jds.2015-9615

Merrill, M.L., Ansotegui, R.P., Burns, P.D., MacNeil, M.D., Geary, T.W., 2007. Effects of flunixin meglumine and transportation on establishment of pregnancy in beef cows1. J. Anim. Sci., $85(6)$, 1547-1554. https://doi.org/10.2527/jas.2006-587

Pugliesi, G., Shrestha, H.K., Hannan, M.A., Carvalho, G.R., Beg, M.A., Ginther, O.J., 2011. Effects of inhibition of prostaglandin F $2 \alpha$ biosynthesis during preluteolysis and luteolysis in heifers. Theriogenology, 76(4), 640-651. https://doi.org/10.1016/j.theriogenology
.2011 .03 .017

Sakatani, M., 2017. Effects of heat stress on bovine preimplantation embryos produced in vitro. J. Reprod. Develop., 63(3), 347-352. https://doi.org/10.1262/jrd.2017-045

Schlapp, G., Goyeneche, L., Fernández, G., Menchaca, A., Crispo, M., 2015. Administration of the nonsteroidal antiinflammatory drug tolfenamic acid at embryo transfer improves maintenance of pregnancy and embryo survival in recipient mice. J. Assist. Reprod Genet., 32(2), 271-275 https://doi.org/10.1007/s10815-0140378-X

Spencer, T. E., \& Bazer, F. W. 2002. Biology of progesterone action during pregnancy recognition and maintenance of pregnancy. Front. Biosci., 7(7), d1879d1898.

von Krueger, X., Heuwieser, W., 2010. Effect of flunixin meglumine and carprofen on pregnancy rates in dairy cattle. J. Dairy Sci., $\quad$ 93(11), 5140-5146. https://doi.org/10.3168/jds.2010-3072

Wiltbank, M.C., Baez, G.M., Garcia-Guerra, A., Toledo, M.Z., Monteiro, P.L.J., Melo, L.F., Ochoa, J.C., Santos, J.E.P., Sartori, R., 2016. Pivotal periods for pregnancy loss during the first trimester of gestation in lactating dairy cows. Theriogenology, 86(1), 239-253 https://doi.org/10.1016/j.theriogenology .2016 .04 .037

\section{How to cite this article:}

Sudhanshu Pratap Singh, Ankesh Kumar, Prakrutik Prafulchandra Bhavsar, Mukesh Sahu, Praveen Kumar and Sushil Kumar. 2020. Evaluation of the Effect of GnRH Analogue, Progesterone and Tolfenamic Acid on Serum Progesterone Profile and Conception Rate in Repeat Breeding Crossbred Cattle. Int.J.Curr.Microbiol.App.Sci. 9(05): 2630-2637. doi: https://doi.org/10.20546/ijcmas.2020.905.301 